\section{PHOTOGRAPHIC REPRODUCTION OF COLOURS.}

THE various methods for producing photographic pictures in colour were described by Sir Henry Trueman Wood at the Society of Arts on February 24, and examples of the results achieved by the different processes were exhibited. The main object of the paper was to bring before the Society M. Chassagne's promising process for the photographic reproduction of colour, but the opportunity was taken to summarise the whole question of colour-photography.

Though the rationale of the new process remains a mystery, there can be no question that very remarkable results are produced. Even more striking than M. Chassagne's pictures, however, are some transparencies exhibited at the same meeting by Mr. Bennetto, of Newquay, in Cornwall. For some time there have been rumours that Mr. Bennetto had obtained satisfactory photographs in colours, but the pictures had only been seen by a limited number of photographers before they were shown at the Society of Arts. His photographs are much clearer than those obtained by the Chassagne process, and look almost like watercolour sketches.

A short account of a private exhibition of some of Mr. Bennetto's results appeared in Friday's Times, and is here abridged. The methods, and indeed the principle, employed remain the secret of the inventor, and it is intended that they shall remain so until several more details and applications of the invention have been more fully worked out. All that is at present known is that the inventor claims to have discovered a system of colour photography by which can be transferred to a photographic negative, and thence printed on glass or paper, the exact natural colours of the object towards which the camera has been directed. He employs no pigments, his plates have not to be washed with various coloured solutions, and it is not necessary to view his pictures through any combination of tinted glasses The colours are imprinted on the plate just as are the light and shade in an ordinary monochrome photograph, and are directly visible to the eye, without any subsidiary apparatus. It may be mentioned that Mr. Bennetto, in his earliest experiments, could get no effects with a less exposure than three minutes; now he is able to work with exposures of sixteen seconds.

In strictness, of course, it is not possible to know for certain that a particular result is produced by a particular process unless the nature of that process is also known; and from that point of view, it is perhaps allowable to regard Mr. Bennetto's pictures with some degree of philosophical suspicion. But he has been put to tests which it is difficult to suppose he could have satisfied did he not in fact do what he claims to do. He was requested to focus his apparatus on an easel. When he had done so, he was blindfolded, and on the easel was placed an impossible picture, painted in impossible colours, which he had never seen before. This he photographed and developed, still without seeing the original, with the result that the impossible colours were reproduced in the photograph obtained.

Whatever may have been the methods used, the pictures produced by them attain a high standard of excellence. One of the best specimens shown was a study of a sunrise, taken early one morning in the middle of June 1895 , in which the fiery orange of the dawn and the heavy masses of cloud were admirably represented. The clouds, again, were excellent in a typical picture of Cornish seashore scenery, and the tints of the sand and rocks, and their reflections in the pools, were faithfully reproduced. In the case of a rock picture with wonderfully brilliant colouring, it was stated that, when the glass plate on which it was printed was examined under a microscope, not only could each individual mussel on the rocks in the foreground be clearly discerned, but that even the iridescent colours on their shells were plainly distinguishable. Perhaps the picture which best illustrated the capabilities of the process was one of a champagne-bottle standing on a white tablecloth, and surrounded with various fruits. Here there were three or four different whites which were all distinguish. able, but which it would probably have taxed the powers of any artist to represent by painting. The gold-foil on the bottle was exactly rendered, and it was possible to tell that it was full by the gleam of the liquid. The inventor looks forward, among other things, to revolutionising by his process the illustration of books and magazines, and hopes to show in the future how to flash a picture on a screen so that a permanent copy may be left behind.

NO. I 427 , VOL. 55$]$

\section{ON THE ALTERNATIONS OF GENERATIONS IN PLANT LIFE. ${ }^{1}$}

$\mathrm{I} \mathrm{N}$ his paper on apospory and allied phenomena (Lin. Trans. Bot., 2nd series, vol. ii. p. 301) Prof. Bower says : "Already the observations of Pringsheim and Stahl have had their effect in demonstrating that no fixed and impenetrable barrier exists between the sporophore and the oophore." The suggestion thus made is far reaching in its consequences; if there be no such fixed and impenetrable barrier, then the distinction between the sporophore and oophore loses at least much of its value, and the anxious assignment of this or that structure to one or the other generation may prove to be labour lost; then the doctrine of the alternation of generations is in peril, and the mind is driven to think of a state of things in which a man should find no impenetrable barrier between himself and his father or his grandmother.

The doctrine of alternation of generations seems, therefore, to deserve reconsideration : and the principal object of the present paper is to endeavour to suggest to the attention of those more capable than myself of forming a conclusion, some considerations towards such a review of at least a part of the subject.

Another question to which I desire to call attention as I proceed is this: whether reproduction is the function of special organs only, or whether it is more or less clearly shown to be a power possessed by the whole organism-a question to which the labours of Weismann have given a fresh interest.

In this review I propose to confine my attention primarily to those classes of plants which produce a cormophyte. I do so, not forgetting that a wider survey of the subject might be yet more valuable. Under the term cormophyte I include the plant of the Characea, whether the description be perfectly accurate or not.

I do not propose to trace the life-history of every group of plants; but I have chosen for consideration groups which exhibit, I believe, types of every important variety of the schemes of life-history to be found in those parts of the vegetable kingdom to which the doctrine in question has been thought to have any application.

To prevent any possible misapprehension, let me say at once that when I use language borrowed from the doctrine in question, such as sporophore or oophytic generation, I do so, not as affirming the doctrine or the consequent fitness of the language, but in the endeavour to understand the view taken of the phenomena under discussion on the footing of that doctrine.

Characee. - In this group we have a sexual generation. The fertilised archegone becomes a fruit or spermocarp; this is detached from the parent organism. It gives rise to a primary root and a hypha-like prothallus, and from the prothallus a young cormophyte is developed like the parent. The succession ot events may then be thus stated :-

Cormophyte producing $\left\{\begin{array}{c}\text { Archegone } \\ \text { Antherizoid }\end{array}\right\}$

Spermocarp or fertilised archegrine. 1

Protonema or proembryo.

Cormophyte.

Now here we must observe that there is one kind of generating cell only, viz. the sexual cell, and that there is no spore in the sense of an asexual cell, and that, as a consequence, there is no sporophytic generation.

On the first blush of the matter, a life-history such as this would seem to present nothing like an alternation of generations. At one time, however, Prof. Vines suggested that the pro-embryo was to be regarded as the sporophore which did not produce spores, but aposporously produced the oophore by direct vege. table growth (see Bower, 2 Lin. Tr., p. 321). He has, however, since altered his opinion, and he now regards the development of the pro-embryo not as indicative of an alternation of generations (Vines on Apospory in the Characee, I Ann. Bot., I77).

1 The accompanying paper reached the hands of the editor of NATURE on 3 I August of last year. Dr. Scott, in his valuable address as the President of the Botanical Section of the British Association, delivered more than a fortnight after that date, has, like myself, discussed the alternation of generations, apospory and apogamy, and the relations of mosses and ferns. These dates will account for my not referring to Dr. Scott's views; and oz the whole I think it better to leave my paper as an independent contribution to these subjects, rather than to attempt to weave into its existing structure any references to the more authoritative contribution of Dr. Scott.-EDw. Fry. 
But side by side with this sexual generation, there is evidence of two other modes of propagation amongst the Characeæ.

(i.) It is believed by some botanists to be established beyond doubt that in the case of Chara crinita in the regions of the Baltic Sea, if not elsewhere, the unfertilised archegones produce plants like fertilised ones.

(ii.) Some species of Chara are propagated by bulbils or agglomerations of cells, by branches known as gymnopodal shoots, or by prothalloid branches.

We are thus in the presence of facts of the last importance on the theory of reproduction. We find an organism with organs specially adapted to and formed for reproduction, and yet the same result is brought about by other parts of the plant, which seem to have no such special organisation.

And, secondly, we find that the result of these short cuts to reproduction excludes or avoids the sexual act.

Muscinea. - Here the full life-history may be represented as follows :-

Oophore ... $\left\{\begin{array}{c}\text { Spore } \\ \text { Protonema } \\ \text { Bud } \\ \mid \\ \text { Cormophyte, Archegone } \\ \text { producing Antherizoid }\end{array}\right.$

Sporophore

Sporogone (seta and sporangium)

dis somewhat elaborate life-history, the mosses exhibit abbreviated modes of reproduction of varied descriptions-a multiplicity of methods of what I will venture to call, by borrowing a term from a popular branch of applied science, short circuiting.

First we get the production on gemmæe which produce protonema like that arising from the spore, and this protonema, through the intervention of a bud, produces the cormophyte.

These gemme are found in a great variety of positions : in the capsules in Encamptodon (Weissia perichatzalzs), in the place of spores (Montagne, "Plantes Exotiques Nouvelles," Ann. de Sc. Nat. Bot., vol. iv. pp. $(19,366):$ in the terminal cups which probably represent male flowers in the well-known Tetraphis pellucida; congregated in balls at the ends of quasi pedicels in Aulacominium palustre; on the ends of the leaves in the Orthotrichum phyllanthum (where the fructification is very rare); in Leptodontium gemmasceus and Grimmia hartmanni; on the upper half of the midrib in Tortula papillosa.

The next step in the abridgement of the life circle is exhibited by those cases in which protonema is produced by the cormophyte without the intervention of a gemma. "Pringsheim and Stahl found independently of one another," says Prof. Bower (ulisup.), "that it is possible by cultivation under abnormal circumstances to induce a formation of protonema by direct vegetative growth from the sporogonium of certain mosses." But nature herself, apparently under no abnormal circumstances, brings about the same phenomenon. Schimper has traced the growth of protonema directly from the rhizoids in Phascum ser. ratum ("Recherches sur les Mousses," p. II), and Polytrichum nanum and aloides (p. 12); from the stems in Dicranum undulatum (p. 13); from the under side of the leaf in Orthotrichum obtusifolium (Pl. ii. fig. 6) ; from the mid-rib of the leaf in Orthotrichum Lyelli (p. 15); from the perichretal leaves in Oncophorus glaucus (p. 18); from the base of the leaf in Funaria hygrometrica (p. I9). It has been found growing from the marginal cells of the involucres of the archegone in the strange Buxbaumia aphylla (Goebel, on "The Simplest Form of Moss," Ann. Bot., vol. vi. p. 355). Lastly, in Conomitrium julianum young plants often grow from the inner side of the calyptra with the intervention of a short piece of protonema (Goebel, "Outlines of Classification," Eng. Tr., p. I73).

But nature goes yet another step forward, and leaves out in some cases at once gemma and protonema; and the cormophyte produces bulbils which at once again grow into cormophytes. Thus on the rhizoids of Barbula muralis, Grimmia pulvinata and trichophylla, and Trichostonnum rigidulum are formed leaf-buds, which develop into the true cormophyte (Schimper, IO-II): bulbils grow on the stem of Bryum annotinum (p. 14) ; and, lastly, we get the striking phenomenon of young cormophytes produced at the ends of the branches in
Sphagnum cuspidatum, resembling in everything but in size the parent plant from which they are produced (Schimper, "Torfossoose," pl. 16, fig. I). This is very striking : here nature has given the slip to spore, to gemma, to protonema, to leaf-bud; short-circuiting can go no further.

The first inquiry I suggest on the foregoing statement of facts is this: Taking the life-history of a moss in its fullest form, is it correct to say that there are two generations involved in it? And this will turn upon what we mean by a generation.

Generation.-If we regard the alternation of generations as it exists in the Medusa and hydroid zoophytes, to which the expression, now so familiar, was, I believe, first applied by Steenstrup, it will be found that in these creatures, each generation consists of a distinct and independent organism, differing from the case of generations of men in that the one generation is produced asexually by germination, and the other sexually, and that the organisms of the two generations are different in form. The generative zooid or Medusa is detached from its stationary parent: and in like manner the young creature produced by the Medusa is detached from it before it begins to develop into the fixed hydroid colony; in the case of each new generation there is a complete solution of continuity with its parent; there is no physical connection maintained after a certain period, and there is no dependence for nutrition or any other vital process. But when we turn to the moss we find no such division into independent organisms between the oophore and the sporophore, but, on the contrary, a continued physical connection, and dependence of the seta and sporogone on the cormophyte. The two parts are organically connected. The seta and sporange are incapable of an independent existence, and are not detached from the moss plant except by death.

I suppose that a generation might, according to the ordinary understanding, be defined to be the life of an organism either independent in fact or constituted for an independent existence from the time when its whole future was gathered up into one cell to its death: but is not usually extended to include the life of a part of an organism from the time when the future of that part was gathered together into a single cell.

How are we to distinguish a new generation from the growth of a part in an existing structure? I suppose that a new generation means the origination of a new individual ; that so long as there is a physical continuity in a given structure, both in fact and in design, we have the same individual ; that so long as this exists, the death of a part of the structure does not convert the remaining part, or the parts which may arise from it, into a new individual; and that, in short, we never have a new generation without the solution of continuity, in fact or in design, between the old and the new. If we adopt the view above suggested of a generation, there is not in the life-history of the moss more than a single generation, and there is consequently no alternation of generations.

To extend the definition of a generation so as to include the separate development of dependent parts, would, no doubt, remind us of the fact that in the earliest stages of organisation. growth and reproduction seem hardly to be distinguished; but it seems to me to confound together two things which it is most important to separate when we are considering the course and history of reproduction.

In this connection it is convenient to consider the meaning of the words ovum or ovule. By these words I conceive that botanists mean a cell resulting from the union of two other cells of different characters, from which cell a new generation starts. The "embryo which begins the new generation is the female or germ cell (ovum, oosphere, germinal vesicle)," says Sachs. That it shall be the beginning of a new generation - of a new being, either independent or constituted for independence, is, I conceive, an essential part of the meaning of the word in question. If so, there is in mosses no ovum and no oophore; for the fertilised archegone produced in mosses is not an independent organism, but a dependent organism or part of an organism; and the really startling fact about this history of the moss appears to me to be this: that whereas in the generality of cases the fertilised ovum is itself and directly the starting-point of a new individual, in the moss the fertilised ovum produces a new growth, and that this new growth by subdivision produces a number of spores, each of which is the starting-point of a new individual. But this process in the mosses does not stand alone. It recalls the mode of reproduction in other cases. In some of the Floridere the fertilised ovum does not directly reproduce a new

NO. I 427 , VOL. 55] 
individual, but a growth takes place, and the ovum becomes differentiated into two parts - the one sterile, which forms a kind of capsule, and the other fertile, which produces numerous spores: and as in Nemalion and Batrachospermum (Bower on "AntitheticAlternation," iv., Ann. of Bot., p. 36r) : in others the growth after fertilisation takes place from an adjoining cell or cells of the procarp (Lejolisia, \&c.) ; or, in other cases, from adjoining procarps to which the fertilising effect is handed on (Corallina, Dudresnaya, \&c.), and this results in the formation of corpospores (Bower, uhi supra). Again, in the Pyrenomycetes, the result of fertilisation is the production of perithecia, or receptacles which again produce asci or sporangia, which in their turn produce spores.

These modes of generation suggest as their probable explanation one or other of two different views. The one view is that the sexual act is in these cases not reproductive, not the startingpoint of a new generation-but productive only, and is the starting-point of a new organ or growth in the parent plant-so that in this view the only mode of reproduction is asexual; the other view, which appears to me the more probable, is that the fertilised protoplasm of the ovum is broken up into various parts, and that, notwithstanding the intervening stages of development, a portion of it finds its way into each so-called spore, so that the spore in all these cases is, in fact, a sexually produced cell, and the only mode of reproduction is sexual.

Perhaps some corroboration of this latter view is to be gathered from the cases in which the archegones of mosses have shown a tendency to reduplicate the growths which they produce. W. Theodor Giumbel " Der Vorkeim-Beitrage zur Entwichlungsgeschichte der Moospllanze. Nova Acta Acad. Cesar.," vol xxiv. part ii. pp. 578-65I) has collected a number of such instances. In the Polytrichum juntiperinum he has found an archegone producing two setæe and two capsules under on calyptra. In Hypum pseudoplumosum he has found two setio grown together and bearing two capsules; in Mnium serratum one seta and two capsules; in Bryun argenteum and Splachmum vasizulosum one seta with two capsule necks and two capsules. These abnormal growths, or some of them, may, perhaps, point to a division of the fertilised protoplasm even in the archegone; and they may be only cases of the earlier beginning of that division which normally takes place after the growth of the sporangium.

If this suggestion should be the true one, it would seem to follow that fertilisation amongst plants may produce one or other of two results: (I) it may directly result in the fertilised ovun capable of producing a new plant, or (2) it may indirectly result in the formation of a number of cells each capable of reproduction; and to this latter form of reproduction that of the mosses should be referred.

Recurring to the brief summary of the modes of reproduction in the Muscinex, it affords room for much observation. We find apogamy in almost every form, i.e. we find various modes, all of which avoid and exclude the sexual union; but the economy of nature goes much beyond that, and excludes the protonema, the gemma, and the leaf-bud. The one thing which is reproduced, whatever else may be omitted, is the cormophyte; this seems to be the one predominant object of nature's care.

IIoreover, it will be observed that nature is careless whether she produces protonema from the one generation or the other: it may arise from the sporangium or the calyptra, which are parts of the sporophore, or from the rhizoid stems or leaves, which are parts of the oophore.

It is, moreover, noteworthy from how great a variety of parts the new organisms spring - whether in the shape of protonema or gemma. It seems as though the whole organism, and not any special parts of it only, were teeming with the capacity for reproduction.

Ferns. - The normal life-history may be represented thus :-

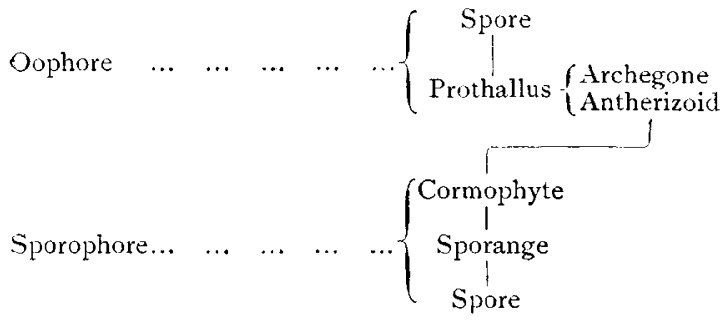

So that whilst in mosses the cormophyte produces the spore; in the ferns it produces the fertilised ovum; or, to express it in the language of the theory under investigation, in the mosses the cormophyte is an oophore; in the ferns it is a sporophore.

But side by side with this normal life-history in the ferns, we have abbreviated forms to which much attention has lately been directed.

We have cases of prothallus (capable of producing the two sexual forms) arising not from the spore, but from the sporange in the Athyrium filix femina, var. clarissima, and in Poly. stichume angulare, var. pulcherrimum; we have prothallus arising from the fronds-from the apex of the pinnule or one of its segments, or from the surface of the pinnule in Polystichum angulare, var. pulcherrimum. (Prof. Bower on "Apospory," ubi sup., and Druery, Four. Linn. Soc. Bot., vol. xxii. p. 437). In Pteris aquilina growths have been found from the sporangia "resembling in some cases moss protonemata, in others irregularly shaped prothalli" (Farlow, "Apospory in Pteris aqulina, 2 Ann. Bot., 383).

So, too, in the genus Trichomanes we find similar growths of prothallus. In Tr. pyxidifertm it grows from the base of the sorus; in $T r$. alatum from the tips of the pinna of the fronds, from the cells of the apices or margins, or from the surface of the fronds: and again in the form of flattened strap-like growth from the margins or tips of the pinnules in Tr. alatum (Bower, "Some Normal and Abnormal Developments of the Oophyte in Trichomanes, Ann. Bot., I, 269). Tr. K'aulfussii presents growths of gemme and outgrowths on the margins of the fronds similar to those of Tr. alatum (Bower on "Apospory and the Production of Gemmæ on Tr. Kaulfussii," 8 Ann. Bot., 465).

We get other cases in which gemmæ are produced, and that in a variety of ways; and whereas in mosses the gemme sometimes give rise to prothallus and never arise from it, in the ferns they seem rather to be produced by the prothallus, and appear to produce the cormophyte by direct vegetative growth. They have been described as growing in large numbers on the margin of the thallus of Vittaria parvinla and Monogramme paradoxa, and on the ends of prothalloid growths in Tr. alatum. They have been observed, too, on Tr. incisum and in certain of the Hymenophyllex (Bower, I Ann. Bot., 273, 283-4).

But nature goes yet two steps further in this process of short. circuiting, In Tr, alatum the prothallus bears flattened expansions from which grow buds, which by the ordinary course of differentiation produce the leaf-stem and roots of a young cormophyte (Bower, I Ann. Bot., 287), and the same phenomenon has been observed in Lastraa pseudomas, var. cristata (Druery, Jour. Linn. Soc. Bot., xxix. 479-48I)

Lastly, as in mosses, even the prothallus stage may be squeezed out. We get a vegetative bud developed from the base of the sorus in Athyrinm filix fo'mina, var. elegnns, or from the side of the sorus in Aspidium (Lastrea) Erythrosornm, var. Monstrum vel proliferum (Bower, 2 Linn. Tr.). The growth of such buds and small plants arising from them on the pinne of Asplenium bulbiparum, Cystopteris bulbifera and other ferns is a familiar sight in our garden houses.

We have thus a young cormophyte produced by direct growth from an old cormophyte-a case of the most simple and short reproduction, and I can hardly bring myself to think that repro. duction without spore or ovum is justly to be regarded as the case of an alternation of generations, one arising from a sexual ovum, and the other from an asexual spore with the aid of two principles or facts-apospory, which gets rid of the spore, and apogamy, which gets rid of the ovum ; such a mode of regarding a simple and direct case of vegetative reproduction seems to me to be unreal, and to savour of scholasticism. Apospory and apogamy are expressions natural enough if we adopt the doctrine of alternation of generations as one which is to be applied to all cases of reproduction in the families concerned, because without some such epicyclic doctrines the facts will not go into the theory ; they are formulæ for classes of exceptions on the supposed rule; but it may be doubted whether the exceptions here are not sufficient to destroy the rule.

If we insist on the view of the two generations, we are struck by the confusion which exists between them, for the prothallus, which is part of the oophore, may arise either from the spore or from the cormophyte, and from the sorus, which are regarded as parts of the sporophore; and the prothallus itself may produce either sexual organs, and so an ovum, or it may produce a cormophyte by direct vegetative growth in the form of a gemma or a bulbil, in which case it is difficult to describe it as an oophore.

NO. 1427 , VOL. 55$]$ 
Another point which strikes the mind on the consideration of the generation of ferns as of mosses, is that the theory of an alternation of generations is applicable only to one out of many modes of generation or schemes of life, and that it fails entirely to explain the others ; and that therefore, even if true, it cannot be a complete or sufficient explanation of the facts in question.

But let us for a brief space confine our attention to the ful and most complex life-history of which it is suggested to be an explanation. The fertilised archegone of the prothallus of the fern does not become detached from the prothallus, but, on the contrary, establishes a closer relation with it by the formation of a sucker or foot, which communicates with the tissues of the prothallus, and draws from them nourishment for the young cormophyte in the course of its growth. When the prothallus has thus performed its functions, it withers away. There has thus never been any physical severance of continuity between the prothallus and the comophyte, and from the firs to the last moment in the life-history of the fern there has been a continuous physical relation. Now arises the question whether the death of the prothallus is like the death of a parent, or the death of part of an organism - that kind of death without which there can be no life. Is it anything more than the casting off of the leaf in autumn, or of the stipules and bracts in the spring, or of the corolla and the stamen and pistil when their part has been lone, or the withering of the cotyledons? Again, I believe that I am right in holding that the prothallus has no adaptation to independent existence; that if the archegone be not fertilised, it does not long maintain its life, and that it is thus in no way fitted for an independent existence. If the view with regard to the meaning of a generation, which I have before suggested, be correct, it would seem that we have no true alternation of generations in the life-history of a fern any more than of a moss; and that, as in the mosses, the sexual union ends in the reproduction of a new individual, not directly, but indirectly only, or (according to another view) in the production of a new part of the existing organism.

A comparison of the life-histories of the mosses and of the ferns discloses, as we have seen, the remarkable fact that in the former the cormophyte is an oophore, and in the latter a sporophore, or, as stated by Hofmeister: "The leafy plant in the mosses answers, therefore, to the prothallium of the vascular cryptogams ; the fruit in the mosses answers to the fern, in the common sense of the word, with its fronds and sporangia", ("On the Germination, \&c., of the Higher Cryptogamia," Eng. Tr., p. 435). If this be correct, it follows that the cormophytes of the two groups have no connection and no relation of descent, for if the fern plant were a modified moss plant, it would obviously belong to the same generation. It follows then that the leaves, the stem, and the whole vegetative structure of the mosses have no genetic connection with those of ferns or of the phanerogams. "The chasm which divides them," says Prof. Goebel (Enc. Brit., s.v., Mrssineer, vol. xvii. p. 74), speaking of these two classes of plants, "is the widest with which we are acquainted in the whole vegetable kingdom."

On this hypothesis then it follows that the mosses are to be regarded as the highest point reached by that line of develop. ment in which the cormophyte is the oophore, or, in other words, in which the chief vegetative growth is also productive of the ovum, or sexually produced cell; and that the ferns are the first and lowest example of that line of development in which the cormophyte is the sporophore, or, in other words, in which the chief vegetative growth produces only the spore or asexual cell. The mosses, therefore, appear before us without descendants, and the ferns without ancestors.

This conclusion seems improbable in itself, but it becomes more strange when we consider the fact that the Hymenophyllace present themselves very much as if they were a link between the mosses and the other ferns; a view which has been long, and still is, maintained by the foremost students of these plants (Bower, "Some Normal and Abnormal Developments of the Oophytes in Trichomanes," i. Ann. Bot., 269, 270). The leaves recall those of mosses, not only in their generally delicate character, but in that they often consist of only one layer of cells, and that, except in one genus, Loxsoma, they are without stomata. Again, as far as is known, the product of the spore of the Hymenophyllaceie is not a prothallus, as in most ferns, but a protonema, as in the mosses. We have already seen that in many cases the protonema of the Hymenophyllacere acts like that of the moss, viz that it produces a bud which produces a cormophyte: and this apogamy appears to be commoner in this group than in any other of the Filices.

If, instead of regarding the successive phenomena of the lifehistory of the moss and the fern as divided into two distinct generations, we regard them merely as successive events in the history of one and the same organism, and further admit the possibility of a variation in the order of these events, then we can conceive that a moss was the ancestor of the filmy fern. We shall hereafter find other cases in which it appears that the order of succession of events has been changed in allied organisms.

Perhaps this variation in the order of the events may be due to, or at least may be associated with, the different methods adopted by mosses or ferns respectively for retaining that moisture in the presence of which alone the act of fertilisation occurs. The moss is adapted to retain the dew and the rain amongst its leaves and in its perichretal growths; and the long translucent hairs, which characterise the leaves of many of the mosses which especially affect dry situations, are probably of use in retaining this moisture. Iosses are for the most part habitually damp. In the ferns, on the other hand, the presence of moisture during fertilisation is assured by an entirely different method; here we have a plate-like expansion of the prothallus, clinging closely to the damp soil and the archegones and antherizoids situate usually upon the under or damp surface. If these different classes of plants are to retain moisture at differenc stages of their life-history, it will seem to follow that fructification which requires this moisture must follow in the order of events this act of retaining moisture. It may be that the order of succession in the events of plant life depend, not on obedience to some inherent law or antetypal form, but on physiological necessities of life.

Rhizocarpece. - In this group, as is well known, we find, for the first time, the presence of two kinds of spores (so called).

The life-history is briefly this. The cormophyte (which is a sporophore) produces two kinds of sporanges-the megasporange and the microsporange. The megasporange produces megaspores, and the microsporange produces microspores. The megaspores are female and without fertilisation produce a prothallus, which bears archegones; and these archegones are fertilised by antherizoids, proceeding from the microspores. From the archegones thus fertilised, the new cormophyte is produced. The life-history may then be thus summarised :-

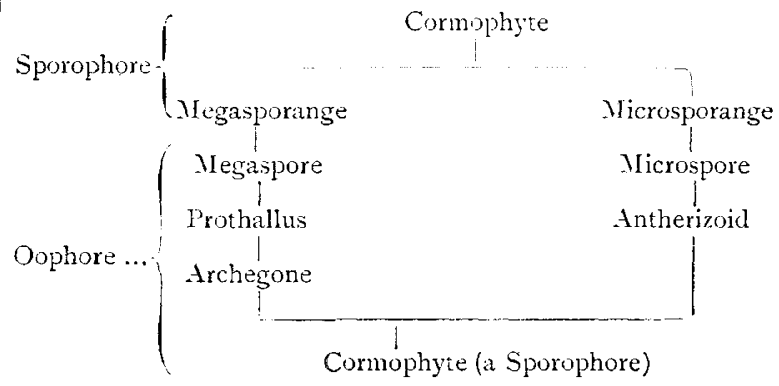

In the foregoing statement a difference as regards the prothallus will be observed between the megaspores and the microspores. The female prothallus is developed as a substantive growth, but in the case of the microspore this appears to be much less clear. "In .Marsilea and Pilulalaria the antherizoids are produced in the interior of the microspores themselves." In Salvinid each microspore emits a tube which pierces the wall of the sporangium and divides into two parts, of which the terminal part is developer into antherizoids, leaving the single cell of the hinder part as the so-called prothallus (Sachs, Text-book by Bennett and Dyer, 384). It may be permitted to doubt whether that single cell can be regarded as a true prothallus; but even if it be, this is absent in Marsilea and Pilularia, so that here, on the male side, the prothallus has dropped out of the series of events.

Another point must be considered. In the case of the moss and the fern passing through the full circuit of their life-history, there are two points at which the whole future of the plant has been thought of as wrapped up in a single cell, viz. in the spore and in the fertilised archegone : in the case of the rhizocarps and all plants which follow their scheme of growth, including the phanerogams, the future of the plant is gathered into a single

NO. 1427 , VOL. 55] 
cell only once in the life-history, viz. in the fertilised archegone. It seems difficult to consider in the latter case that there is more than one generation.

Can it be rightly said that in the case of the Rhizocarps there is any true spore or any true sporophore? The answer depends on the meaning which we attribute to the word spore.

Of this word many uses are made, to the confusion of thought on such subjects. It is according to the glossary to Kerner's "Natural History of Plants," as edited by Prof. Oliver, "a reproductive cell which becomes free and is capable of developing into a new indiviuual." De Bary, in like manner, applies the term generally to " any cell which as a single cell becomes free and is capable of direct development into a new organism (Bion) without reference to its origin and homology" (cited by Bower, ii. Limn. Tr., 30I.) Sachs, on the contrary, would appear to confine the term to such a cell when asexually produced. "The asexual reproductive cells," he says, "usually become detached from the mother plant and dispersed (hence called spores) in order to produce a new generation at a distance from it "(Bennett and Dyer's Translation, p. 203): and in the language which contrasts oophore and sporophore, I suppose this view that the spore is asexually produced is plainly involved.

Now if we take either of these definitions and apply it to the life-history of the Rhizocarps, a curious result appears to follow. Inasmuch as the megaspore produces a prothallus of its own energy, it may fall under the description of a spore, and may be considered as the product of a sporophore and the beginning of an oophore. But neither the microspore nor the antherizoid of Marsilea and Pilularia falls under such a definition, and there seems nothing to separate it from the sporophore as a new generation, and yet the archegone of the megaspore is fertilised by it. If I follow the matter aright, the sporophoric generation on the female side has united with the oophoric on the male side for the production of the young cormophyte. If this be true, there is certainly no hard and fast line between sporophore and oophore, for the cormophyte is the one by one parent and the other by the other parent.

If the capacity to reproduce an organism like the parent be essential to the conception of a spore, then neither megaspore nor microspore is a true spore, and we have no sporophoric generation on either side.

I.ycopods. - In this single group we have a most remarkable diversity of schemes of generation.

The Selaginellacere (as is well known) produce megaspores and microspores, and present substantially the same scheme as the Rhizocarps.

The Lycopocliacere, on the other hand, have a prothallus produced by a spore, and itself in turn producing archegones and antherizoids, from the union of which arises the cormophyte, which is regarded as being a sporophore. This group, therefore, presents substantially the same scheme as the Ferns.

Here, then, we have two groups of plants which botanists have agreed in regarding as closely united the one to the other, yet pursuing essentially different courses as regaxds reproduction. The two courses are so opposed, that whilst the sexual differen. tiation arises in the Lycopodiacex only in the oophore, in Selaginella it goes back into the sporophore ; or otherwise stated, in the one this clifferentiation begins in the prothallus, in the other it begins before the prothallus by the differentiation of the spores into two kinds. What is the inference? Is it not this? tha neither the modes of reproduction, nor the order of events in ${ }^{t}$ the life-history are characters of great persistency; or, in other words, that the organism is unstable in all these particulars?

The Lycopods exhibit the phenomenon of short cuts. In $L$. cernumm it has been found that the root tops (sic) turn into root gemme or bulbs, which produce on germinating young plants much like those from the prothalli (Treub., "Some Words on the Life History of Lycopods," Amm. Bot., pp. I19, 122).

Phanerogans.-The accepted application of the doctrine of the alternation of generations to this class of plants may thus be stated.

The cormophyte of the Phanerogam is, as in the Ferns, a sporophore.

\section{The ovule}

The the megasporange

The endosperm $=$ the female prothallus.

The pollen sac $=$ microsporange.

The pollen grain $=$ microspore

The pollen tube $=$ antherizoid.
According to this view, the life-history of a Phanerogam may be thus stated :-

\begin{tabular}{|c|c|c|}
\hline \multirow{4}{*}{$\begin{array}{l}\text { Sporo- } \\
\text { phore }\end{array}$} & \multirow{2}{*}{\multicolumn{2}{|c|}{ Cormophyte }} \\
\hline & & \\
\hline & $\begin{array}{c}\text { Ovule } \\
\text { (Megasporange }\end{array}$ & $\begin{array}{c}\text { Pollen sac } \\
\text { (Microsporange) }\end{array}$ \\
\hline & & $\begin{array}{l}\text { Pollen grain } \\
\text { (Microspore) }\end{array}$ \\
\hline & $\begin{array}{c}\text { Embryo sac } \\
\text { (Megaspore) }\end{array}$ & $\begin{array}{l}\text { Pollen tube } \\
\text { (Antherizoid) }\end{array}$ \\
\hline Oophore & $\begin{array}{l}\text { Endosperm } \\
\text { (female prothallus) }\end{array}$ & \\
\hline & Cor & ophore) \\
\hline
\end{tabular}

So that the dividing line between the two generations is, according to the theory in question, drawn in the same way as in the Rhizocarps, and seems open to the same observation of the mingling in pollination of two generations.

With regard to phanerogams, no fact is more familiar than that the embryo, i.e. the young oophore, is intimately connected with and is nurtured by the cormophyte, i.e. the sporophore, and thus the two so-called generations coexist in close physical union; and, furthermore, it is familiar that the fertilisation of the embryo sac (or megaspore) by the pollen tube (or antherizoid) often produces great changes in the carpels and the other parts of the perianth, and, in fact, in the whole flowerbearing axis; so that the fertilisation of the mother of a future organism is followed by great physical alterations in the structure of the grandmother.

Another familiar fact is this. In Gymnosperms the endosperm is formed long before fertilisation, whereas in the Angiosperms it is formed after that event. Now, as in the Rhizocarps so in the Phanerogams, we have only the supposed female prothallus left, for the pollen is formed without prothallus; and now, in the Angiosperms, we find the prothallus not coming into existence till after the formation of the ovule (or megasporange) and the embryo sac (or megaspore), and the fertilisation of this by the pollen (or microspore). What was regarded as a pro embryo is now a post embryo: the parent has become the child. The prothallus has, therefore, according to the theory in question, lost its old position of a growth preceding the sexual or, at least, the female organs, and does not arise til after these; it has lost its old function of producing thes organs; and, one may add, it has lost its old form, for it i no longer a prothalloid growth and no longer a substantiv organism, but is reduced to a part of the seed.

In the case of the Cryptogams, the prothallus for the mos part shows its true place in the order of events by gradually withering and dying away when the cormophyte has been started ; but in the Phanerogams the endosperm is only entering on its functions when the development of the embryo begins, for it then becomes filled with nutriment, and increases in size. In a word, its duties are essentially connected with the life and growth of the embryo, so that it is functionally, as well as physically, part of the seed.

If the homology of structures so different in form, function, and order of succession, as the prothallus of Cryptogams and the endosperm of Phanerogams is to be maintained, cogent evidence ought, one would think, to be forthcoming.

The Phanerogams, no less than the other groups which we have been considering, give abundant evidence of short-circuiting. It will be enough, briefly, to refer to some instances.

The gemme which are found growing on the margins of the leaves of the Malaxis paludosa recall curiously the similar, though less complicated organised, structures in the Tetraphis, the Orthotrichum, and other mosses.

Bulbils are found in many cases on the stem in the axils of the leaves. Ranunculus ficaria, Dentaria bulbifira, Lilium bulbiforum are amongst the plants which present this fact.

Small young plants arise directly on the leaf in certain cases, as in Cardamine palustris, where the young plant arises at the bifurcation of the vascular bundles : and in many other cases they arise from the leaves upon the severance of the leaf from the plant, so that an injury to the parent leads to reproduction. 
The Begonias are, as is well known, propagated from leaves to a large extent in our greenhouses; the Hoya carnosa and the Aiuba japonica exhibit the same phenomenon.

Buds are formed on the roots of trees, shrubs, and herbaceous plants, which are capable of the direct production of young plants of the same kind as the parent. Every one knows that the gardener avails himself of this familiar fact for the purpose of increasing his stock in a very large number of plants. One point only requires further mention, viz. that the tendency to produce young plants from roots is in some cases produced, and in others is greatly increased by the destruction of the parent plant. This seems to show that the same cells or parts of the plant which, during the continued life of the parent, assisted in its vital functions, have, by reason of its destruction or death, been diverted to new duties. The same part, therefore, is alike adapted to, or at least capable of, nutrition and reproduction.

Buds are formed on and around the underground bulbs of a large number of plants; no mode of reproduction is more familiar to our gardeners.

Buds, again, are produced in some cases on the subterranean stems, as in Stellaria bulbosa.

In many cases flowers are replaced by bulbils : Polygonum viviparum and bulbiforum, Saxifraga cermua, nivalis and stellaris, Juncus alpinus and supinus, Aira alpina, Festuca alpina and mpicaprina, Poa alpina and conisia are cases in which perfectly formed flowers are often produced, but in which small bulbils frequently, and especially in alpine or arctic regions, take the place of the flowers. (2 Kerner by Oliver, 454.) These bulbils are detached from the parent plant, and throw roots downwards and stems and foliage upwards. A somewhat analogous growth has been found in the Nymphac lotus var. monstrosa (Barber, "On a Change of Flowers to Tubers in Nymphiea lotus var. monstrosa," Ann. Bot. iv. 105). After the development of the sepals, instead of the production of petals and stamens there was formed a bud of green leaves, which developed into a tuber from which a young plant arose. In the persistence of the flower's stalk and sepals, this case differs from that presented by such plants as the Polygonum viviparum.

Lastly, one of the most interesting cases of vegetative reproduction is that of parthenogenesis, or the production of seeds by the female plant without the co-operation of pollen. This appears to be established beyond doubt in the case of the Calebogyne ilicifolia, and probably in the cases of the hemp the Mercurialis annua and Gnaphalium alpinum. This mode of reproduction strikes the mind as very remarkable, because it shows that even in very highly organised plants parts which had been specially provided for reproduction under the stimulus of the pollen cell, still retain the capacity of reproduction even without that stimulus.

It is obvious from these familiar facts that the capacity of re. production is retained by a great part of the organism in many plants, and that it is not excluded by the fact that the part in question may be highly and definitely organised for some other purpose than reproduction, or that it may be intended, according to the analogy and the common course of nature, for reproduction only after the stimulus of fertilisation.

\section{CONCLUSions.}

The doctrine (to use an ambiguous word) of the alternation of generations may be regarded in several lights : as a compendious statement of facts ; as an analogy ; as something to be inferred in ancestral forms from existing ones.

If we mean by a generation the life of an independent organism from the time when its whole future was gathered up in one cell, it seems never to represent the facts of vegetable growth; if by it we mean the dependent life of part of an organism from a single cell, it appears to summarise the facts of the full lifehistory of ferns and mosses, but not of the Rhizocarps or of Phanerogams.

If we regard the doctrine as an analogy, the points in which the analogy breaks down, and the continued recurrence to exceptions to make it agree with the various facts, seem to rob it of much value.

If the alternation of generations be put before us as a fact which the phenomena of existing vegetable life require us to assume in the past, it seems at least doubtful whether more can be justly said than that amongst many modes of reproduction and many schemes of life-history, an alternation of generations in the sense in which it exists in the mosses and ferns may probably be considered as one; but there seems to be nothing to show that it was ever a dominant scheme of life.

The brief review of familiar facts above given seems to tend towards the following conclusions, which I submit with all deference to those better capable of appreciating the question than I am.

(I) That in the language of Prof. Bower, "no fixed and impenetrable barrier exists between sporophore and oophore," but that, on the contrary, the one is capable of passing over to the other, and that the alternation of generations is not an accurate statement of facts or a useful analogy.

(2) That a truer presentation of the facts is to be found in the statement that fertilisation in a plant does not always result in the direct production of a fertilised ovum capable of producing the cormophyte, as in the Characex and the phanerogams, but that it may result in the indirect production of a number of fertilised cells, as in the mosses and some fungi, or, as an alternative view of the same facts, in the direct production of a new part of an existing organism.

(3) That (to repeat the foregoing statement in another form) the different generations in the life-history of any given plant are not separate organisms, but different stages or parts of the same organism.

(4) That when the like events can be found in the lifehistory of different plants, the order of the succession of events is unstable, and that the first may become last and the last first, according as the physiological circumstances of the plant give scope for the action of that reproductive capacity with which the whole plant seems to be endowed.

(5) That this instability exists, even in the sexual act, as regards its place and time in the order of the succession of events.

(6) That the events which occur in the full life-history of a plant admit of short-circuiting or abbreviation, and that in such abbreviated life-histories the one thing which nature appears to desire to avoid is the sexual act, and that the one thing which it appears to desire to preserve is the cormophyte.

(7) That the passage from the life-history of the moss to that of the fern may be accounted for by a transposition in the order of events, and that by such a transposition a moss may be regarded phylogenetically as the direct ancestor of the filmy fern, and the indirect ancestor of all the other ferns.

(8) That, assuming that there is a germ plasm distinct from somatic plasm, and that the presence of the former is essential for the reproduction of the organism, there is evidence of the wide diffusion of the germ plasm, and that no limit to its presence has yet been ascertained.

(9) And lastly, that the reproductive energy operates in plants in such a variety of ways, and under such varying circumstances, as to make it improbable that the facts of reproduction can, with our present knowledge, be reduced to any one scheme, or referred to any single archetype. EDW. FRr.

\section{UNIVERSITY AND EDUCATIONAL INTELLIGENCE.}

OxForn.--On Tilesday, February 16, Convocation decided to confer by decree the derree of M.A. on Dr. J. S. Haldane, Lecturer in Physiology, and on Dr. W. B. Benham, Aldrichian Demonstrator in Comparative Anatomy.

Messrs. W. W. Fisher (C.C.C.), W. Hatchet1-Jackson (Keble), W. S. Church (Ch. Ch.), W. Collier (Exeter), S. H. West (Ch. Ch.), I. F. Marsh (Balliol), and G. W. S. Farmer (Balliol) have been elected members of the Board of the Faculty of Medicine.

The following have been elected Members of the Board of the Faculty of N Natural Science:-Messrs. C. Leudesdor (Fellow of Pembroke), D. H. Nagel (Fellow of Trinity), E. H. Hayes (Fellow of New Coll.), J. W. Russell (Merton), J. WValker (Ch. Ch.), F. J. Jervis Smith (Trinity), A. Thomson (Exeter, Professor of Human Anatomy), W. W. Fisher (C.C.C.), and V. II. Veley (University).

On Monday, March I, Prof. E. E. Barnard exhibited some of his astronomical photographs in the Examination Schools.

Mr. A. C. Le Rossignol (Exeter Coll.) has been elected to an Exhibition in Natural Science at Exeter College on the foundation of King Charles I.

Captain W. de W. Abney, C. B., F. R.S., has accepted the invitation of the Junior Scientific Club to deliver the Robert Boyle Lecture for I 897 . 